\title{
SOLUTIONS IN HANDLING STUDENT STRESS DURING HOME LEARNING USING GAMES LEARNING METHOD
}

\author{
Dedy Panggabean ${ }^{1}$ \\ ${ }^{1}$ Sekolah Lentera Harapan Tomohon \\ Email: dedypanggabean1795@gmail.com
}

\begin{abstract}
The pandemic period makes students feel pressured in the distance learning process. They admit that they are stressed and confused to do various activities that support their productivity. This stress they experience during distance learning results in their passivity while learning. This study aims to find the best solution in dealing with student stress during the distance learning period. Method used in this research is games-based learning. Subjects in this study were 90 grade VIII students, on November 02, 2020 - November 13, 2020, and were conducted at the Lentera Harapan Tomohon School, North Sulawesi. This research uses questionnaire sheet instruments, observation sheets, and interview sheets in the data collection process. The data that has been collected is processed using descriptive statistical data collection techniques. Based on the data collected, it was proven that students experienced stress during distance learning. The results found were $90.67 \%$ of students were bored, $81.67 \%$ of students were not productive and often complained. The research finally found that the games method was very suitable for the students' current conditions, because $89.33 \%$ of students were very happy with this method. The results of this study can be taken into consideration to create meaningful learning and reduce student stress levels. As a suggestion, it is important for all stakeholders in education to undertake similar research to see the progress of students going forward.

Keywords: Games, Home Learning, Stressed
\end{abstract}

\section{INTRODUCTION}

Education is a conscious and planned effort to create an atmosphere of learning and an active learning process with the hope of making children develop in spiritual, mental and social aspects. The teacher's contribution in realizing student involvement in the middle of the learning process should be intentional and always nurtured (Irawan, and Ningrum, 2016). Learning is basically a process to develop every aspect in students. Learning should cultivate many aspects that are sure to be useful for the future, and that must be changed. These changes include changes in cognitive (knowledge), affective (attitudes) and psychomotor (skills) (Ardiansyah, Sugita and Awuy, 2017). Based on the above opinion, it is important for teachers to review how the teaching and learning 
process is carried out. If indeed it is a good thing to make children actively involved in learning, then even in the home learning period it must be realized. Based on research conducted by Psychiatry Research in China during the pandemic on 7,200 people, it was found that more than one-third of them had anxiety, more than a fifth had signs of depression, and $18 \%$ had trouble sleeping. This indicates that students are under threat of stress (Huang \& Zhao, 2020).

The researcher also wanted to see how the current condition of students, especially at the Lentera Harapan Tomohon School. A pandemic that is so long has made students and teachers very bored at home. This can be seen from the students' reactions during the learning process. Many of them claim to be stressed, bored, bored, and depressed by the many things they have to do, and at the same time they are very confused. Such pressure makes them passive and unwilling to get involved. When the learning process was running the researcher saw the students were very discouraged. This was clearly seen when the teacher asked questions and there were no students who gave a response, when they were asked to turn on the camera at a virtual meeting, still no one wanted to do it. Even quite easy assignments had many complaints from them. Students who are usually very good at carrying out their responsibilities do not look optimal. Like the goal of Indonesian education, which is to educate the nation's life, with an independent learning program it would not be possible to achieve it if students only became recipients of information and were not actively involved. The gap between ideal conditions and reality on the ground should be adjusted accordingly.

Based on the background above, by using questionnaire instruments, observation sheets, and interviews, the researchers found that students wanted learning that provided freshness in thinking. They also said they wanted fun learning. They also admit that this boredom keeps them from engaging in learning and feels bored and stressed while at home. Researchers found virtual classrooms to be quiet, and learning became one-way like conventional learning. If this is not handled immediately, the process of maximizing human resources with dignity is written in Law No. 20 of 2003 concerning the objectives of National Education Chapter II Article 3 will not possibly be realized. 


\section{LITERATURE REVIEW}

\section{a. Stress level}

Along with the times, the science of psychology that discusses stress levels is also growing. Basically, the theory that discusses stress levels is divided into several approaches, namely: stimulation, transactional, and response stress models (Lyon, 2012). These three models are fundamentally different, but they are closely related in the process of occurrence. This stimulation model stress relates to things that are received directly, either from outside or from within. If the stress model is not resolved immediately, it will enter into a transactional model that talks about cause and effect. Furthermore, if this process continues, the response model will emerge in real action. Basically, this stress response model is a stress model that is very easy to observe, but difficult to control (Lumban Gaol, 2016). If students are not handled intensively, then this stress level will be very dangerous for them and their environment (Lin, \& Huang, 2014).

\section{b. Home Learning}

Regulation of the Minister of Health Number 9 of 2020 concerning Guidelines for LargeScale Social Restrictions (PSBB) in the Framework of Accelerating Handling of Covid-19 article 13, clearly states that all work activities in the office are carried out temporarily online (Kemenkes RI, 2020). In particular, in the circular sent by the Ministry of Education and Culture, the learning process must also be carried out from each house. This was done to prevent the emergence of a new cluster group in the spread of Covid-19 (Mendikbud RI, 2020).

\section{c. Games Learning Method}

The game learning method is a method that is in great demand by students, and this method will stimulate children to be more active and involve students. Students will be more comfortable when studying and of course their learning motivation will increase. It turns out that this learning method will also increase sensitivity and better social attitudes (Susanna, 2017). 


\section{FORMULATION OF THE PROBLEM}

Based on the description of the problem based on the literature review, the problem formulations in this study are:

1. What is the psychological condition of students during the home learning process?

2. How to reduce students' stress levels during the home learning process?

\section{METHODOLOGY}

This research was conducted using descriptive methods with qualitative data elaboration. This research was conducted at the Lentera Harapan Tomohon School, North Sulawesi. This research was conducted for two weeks from 02 November 2020 - 13 November 2020. The subjects of this study were 90 grade VIII students. Data collection instruments used in this study using questionnaires, observation sheets, and interviews.

A questionnaire is a tool used by researchers to obtain data and information related to the problem being discussed. This questionnaire will greatly facilitate researchers in the processing of data that has been collected (Ferdianto, and Ghanny, 2014). This instrument was chosen by the researcher in the hope that all questions are answered seriously by students, because it is easy to choose answers, and does not require further explanation.

Observation sheet is a way of obtaining data or information directly or indirectly. Observations are considered capable of providing reports of a situation systematically, and are easy to believe (Renaldi, 2014). Researchers make observations on how students respond, and their various actions that can be observed. The results of these observations will later be juxtaposed with the results obtained through other instruments.

Interviews are a set of lists of questions asked of respondents with the aim of obtaining the required information. This instrument can be said to be the most accurate instrument, because questions can be made into open questions and systematic. This type of instrument is also flexible (Adadan and Savasci, 2012). This explanation convinced the researcher of the validity of the data to be obtained later. In addition, interviews can provide very in-depth answers, and conclude the number of problems that actually occur (Gurel, et al., 2015).

All data that has been collected will be analyzed using descriptive statistical processing techniques. This type of processing technique allows all data collected and processed more easily 
understood by each reader. The processing is also simple, and it doesn't take long to be able to conclude the results of each data that will be processed (Poluan, and Pangemanan, 2014). Basically, all data and information will contain a few numbers, and that too will be described, this aims to make it easier for readers to understand the contents of this research.

\section{RESULTS AND DISCUSSION}

The data in this study were taken by using questionnaire instruments, observation sheets, and interviews.

\section{a. Questionnaire}

Based on the various questions given regarding the condition of students at home, using a questionnaire and it was distributed to 90 students online, the following results were obtained:

\section{Questions 1. Do you feel bored learning from home?}

Table 1.1

\begin{tabular}{cccc}
\hline Grade & $\begin{array}{c}\text { The number of } \\
\text { students }\end{array}$ & $\begin{array}{c}\text { Percentage Answered } \\
\text { "Yes" }\end{array}$ & $\begin{array}{c}\text { Percentage Answered } \\
\text { "No" }\end{array}$ \\
\hline $8 \mathrm{~A}$ & 30 & $90 \%$ & $10 \%$ \\
$8 \mathrm{~B}$ & 30 & $92 \%$ & $8 \%$ \\
$8 \mathrm{C}$ & 30 & $90 \%$ & $10 \%$
\end{tabular}

Question 2. Do you often feel confused about doing something outside of learning?

Table 1.2

\begin{tabular}{cccc}
\hline Grade & $\begin{array}{c}\text { The number of } \\
\text { students }\end{array}$ & $\begin{array}{c}\text { Percentage Answered } \\
\text { "Yes" }\end{array}$ & $\begin{array}{c}\text { Percentage Answered } \\
\text { "No" }\end{array}$ \\
\hline $8 \mathrm{~A}$ & 30 & $71 \%$ & $29 \%$ \\
$8 \mathrm{~B}$ & 30 & $78 \%$ & $22 \%$ \\
$8 \mathrm{C}$ & 30 & $78 \%$ & $22 \%$ \\
\hline
\end{tabular}

Question 3. Do you often feel anxious, difficult to understand, and stressed at home?

Table 1.3 


\begin{tabular}{cccc}
\hline Grade & $\begin{array}{c}\text { The number of } \\
\text { students }\end{array}$ & $\begin{array}{c}\text { Percentage Answered } \\
\text { "Yes" }\end{array}$ & $\begin{array}{c}\text { Percentage Answered } \\
\text { "No" }\end{array}$ \\
\hline $8 \mathrm{~A}$ & 30 & $79 \%$ & $21 \%$ \\
8B & 30 & $83 \%$ & $17 \%$ \\
$8 \mathrm{C}$ & 30 & $83 \%$ & $17 \%$ \\
\hline
\end{tabular}

After seeing the problems in students, the researchers took further action by offering learning method options for them. After they choose the method that they think is the best, the researchers then investigate their choice more deeply. The data below is the result of this process.

Questions 1. In your opinion, what learning methods are most suitable to be given by the teacher during home learning?

Table 1.4

\begin{tabular}{cccccc}
\hline \multirow{2}{*}{ Grade } & \multirow{2}{*}{$\begin{array}{c}\text { The number } \\
\text { of Students }\end{array}$} & $\begin{array}{c}\text { Learning with } \\
\text { games }\end{array}$ & $\begin{array}{c}\text { Learning by } \\
\text { modules }\end{array}$ & $\begin{array}{c}\text { Learning } \\
\text { with videos }\end{array}$ & $\begin{array}{c}\text { Learning with } \\
\text { virtual }\end{array}$ \\
\hline $8 \mathrm{~A}$ & 30 & $79 \%$ & - & - & $21 \%$ \\
$8 \mathrm{~B}$ & 30 & $82 \%$ & - & $1 \%$ & $17 \%$ \\
$8 \mathrm{C}$ & 30 & $83 \%$ & - & - & $17 \%$
\end{tabular}

Question 2. Does learning with the games method with the teacher reduce your boredom?

Table 1.5

\begin{tabular}{cccc}
\hline Grade & $\begin{array}{c}\text { The number of } \\
\text { students }\end{array}$ & $\begin{array}{c}\text { Percentage Answered } \\
\text { "Yes" }\end{array}$ & $\begin{array}{c}\text { Percentage Answered } \\
\text { "No" }\end{array}$ \\
\hline $8 \mathrm{~A}$ & 30 & $87 \%$ & $13 \%$ \\
8B & 30 & $94 \%$ & $6 \%$ \\
$8 \mathrm{C}$ & 30 & $87 \%$ & $13 \%$
\end{tabular}

Question 3. Do you feel happy and excited when the teacher provides games?

Table 1.6

\begin{tabular}{cccc}
\hline Grade & $\begin{array}{c}\text { The number of } \\
\text { students }\end{array}$ & $\begin{array}{c}\text { Percentage Answered } \\
\text { "Yes" }\end{array}$ & $\begin{array}{c}\text { Percentage Answered } \\
\text { "No" }\end{array}$ \\
\hline
\end{tabular}




\begin{tabular}{llll}
\hline $8 \mathrm{~A}$ & 30 & $91 \%$ & $9 \%$ \\
$8 \mathrm{~B}$ & 30 & $95 \%$ & $5 \%$ \\
$8 \mathrm{C}$ & 30 & $91 \%$ & $9 \%$
\end{tabular}

After the questionnaire instrument was distributed, the researcher continued by making observations. The available observation sheet contains their condition when they have not been given the game method and after.

\section{b. Observation Sheet}

Table 1.7

\begin{tabular}{llll}
\hline No. & \multicolumn{1}{c}{ List of Observation } & Yes & No \\
\hline 1 & Students look not excited during learning & V \\
2 & $\begin{array}{l}\text { Students do not want to be actively involved in learning (quiet } \\
\text { class) }\end{array}$ & V \\
3 & Students do not work and responsibilities optimally & V \\
4 & Students often complain and are late in collecting assignments & V \\
5 & $\begin{array}{l}\text { Students have not been able to do their responsibilities } \\
\text { independently }\end{array}$ & V
\end{tabular}

After the games learning method was implemented, a significant change was seen in the way students learn.

\section{Table 1.8}

\begin{tabular}{llll}
\hline No. & \multicolumn{1}{c}{ List of Observation } & Yes & No \\
\hline 1 & Students look excited during learning & V \\
2 & Students want to be actively involved in learning (class is not & V \\
& quiet) & V \\
3 & Students do their duties and responsibilities maximally & V \\
4 & Students rarely complain and are not late in collecting & \\
& assignments
\end{tabular}


Researchers look deeper into existing problems by conducting interviews with several random people. The results below indicate information that deserves to be considered as supporting data obtained through other instruments.

\section{c. Interview}

Table 1.9

\begin{tabular}{lll}
\hline No. & \multicolumn{1}{c}{ List of Questions } & \multicolumn{1}{c}{ Answers } \\
\hline 1 & $\begin{array}{l}\text { How do you feel when studying online at } \\
\text { home? }\end{array}$ & Very bored with repetitive activities. \\
2 & $\begin{array}{l}\text { What do you think the teacher should do } \\
\text { to make learning fun? }\end{array}$ & $\begin{array}{l}\text { It is better if the teacher gives ice } \\
\text { breaking at the beginning, and also at } \\
\text { the end for review. }\end{array}$ \\
3 & $\begin{array}{l}\text { How do you feel about the many } \\
\text { responsibilities of the teachers at home? }\end{array}$ & $\begin{array}{l}\text { Pretty happy, but if there is assistance } \\
\text { from parents. }\end{array}$ \\
4 & $\begin{array}{l}\text { What obstacles do you often face when } \\
\text { studying online? } \\
\text { Do you feel bored and stressed learning } \\
\text { from home? }\end{array}$ & $\begin{array}{l}\text { Network, and often do not understand } \\
\text { because they are bored, and sleepy. } \\
\text { Really, confused about what to do. }\end{array}$
\end{tabular}

\section{DISCUSSION}

Based on the data collected and described above, it is clear that based on the questionnaire collected, almost all students feel very bored learning from home (90.67\%). Boredom makes them confused to act more productively, so they are confused (75.66\%). Students also think that they often feel anxious, have difficulty understanding, and stress at home (81.67\%). According to the expert's view, if the percentage of a questionnaire distributed shows $75 \%$, then a problem can be 
said to be serious and must be addressed immediately (Djamarah, 2010). These considerations convince researchers that in general students are experiencing periods of saturation and will lead to stress (Table 1.1-Table 1.3). Apart from using the questionnaire instrument, it was clear that students did experience stress when learning at home through the observation sheet. The observation sheet clearly shows that the student is very inactive, often complains, is late in collecting assignments, and does his responsibilities not wholeheartedly. Students also seem unable to do their assignments independently. This data has a very close correlation with student learning conditions during the learning process.

Researchers want to provide a stimulus by offering four types of learning methods, namely: games, videos, modules, and virtual meetings. So, it can be seen that there are $89.33 \%$ of students who really want the teacher to provide the games method while teaching (Table 1.4). This data helps researchers to carry out games-based learning actions. This means that students have a desire for a method that is more relaxed and attractive. Finally, the researcher used this method to see if there were significant changes in student learning patterns. Both in terms of response during learning, and also in terms of doing their assignments.

It turned out that after they were given this method, they were more active, willing to be involved in class, the complaining attitude began to fade, and carrying out their responsibilities to the fullest were visible (Table $1.5 \&$ Table 1.8). The learning situation after being given the games method is very different from previous learning. This convinced the researcher that the game learning method was very good to support in reducing the stress period of students. It is very convincing again when the interview results are seen. Students openly say that they experience stress at home. Lots of tasks, explanations that are not easy to understand, and teaching methods that are not attractive. Students stated that it is very important for teachers to find interesting methods, especially at the beginning and at the end of learning (Table 1.9).

Based on the results that have been described by the researchers above, specifically for each existing discussion, it is important to communicate to each student and parents the current conditions experienced by students. Conditions that are understood by parents and students will certainly facilitate handling in the future. Awareness of self will help each person be more concerned about what to do for himself. This condition requires that everyone is sensitive to their self and struggles to find solutions to their psychological problems (Stahl, and Goldstein, 2010). 


\section{CONCLUSION}

The condition of students psychologically while studying at home has a lot of stress problems. This if allowed to continue will have an impact on other serious problems. The teacher must be able to find the best way to carry out the learning process in each class. This research proves that by providing games-based learning, students are very enthusiastic and active. The majority of students said that they were very comfortable in learning when the game method was given by the teacher, and it calmed the mind. This of course will also trigger a return to interaction between students who had been missing during the Covid-19 pandemic.

A person is said to be mentally healthy when they are able to understand their abilities and can control and deal with self-pressure, so that they can be involved in the community and work in a normal life (WHO, 2013). So, seeing the importance of mental health, the teacher must take it seriously. So as a suggestion for every stakeholder in education must consider these conditions and solutions as a means to help students who are currently in trouble. It is also important to carry out periodic research on similar issues to find other methods that will be of use to each student.

\section{REFERENCES}

Adadan, E. dan Savasci, F., (2012). An analysis of 16-17-year-old students' understanding of solution chemistry concepts using a two-tier diagnostic instrument, International Journal of Science Education, Vol 34, No 4.

Ardiansyah, Sugita, G., \& Awuy, E. (2017). Peningkatan Pemahaman Konsep Hubungan Antar Satuan Panjang Melalui Model Pembelajaran Kooperatif Tipe STAD Pada Siswa Kelas IV SD Inpres 2 Toribulu. Jurnal Kreatif Tadulako Online, Vol. 6 No. 5ISSN 2354-614X. 1-10.

Djamarah, S. B., \& Zain, A. (2010). Strategi belajar mengajar. Jakarta: Rineka Cipta. 
Ferdianto, F. \& Ghanny. (2014). Meningkatkan kemampuan pemahaman matematis siswa melalui problem posing. Jurnal Euclid, 1(1), 1-8. Diambil dari www.fkipunswagati.ac.id/ejournal/index.php/euclid/article/.../7.

Gurel, D.K., Eryilmaz, A. dan McDermott, L.C. (2015). A Review and Comparison of Diagnostic Instruments to Identify Students' Misconceptions in Science, Eurasia Journal of Mathematics, Science \& Technology Education, Vol 11, No 5, Hal 989-1008, 513-544.

Huang, Y., \& Zhao, N. (2020). Generalized anxiety disorder, depressive symptoms and sleep quality during COVID-19 outbreak in China: a web-based cross-sectional survey. Psychiatry Research, 288(March), 112954. https://doi.org/10.1016/j.psychres.2020 .112954

Irawan, F., J., \& Ningrum. (2016). Pengaruh penggunaan model cooperative learning tipe group investigation (gi) terhadap hasil belajar prakarya dan kewirausahaan (pkwu) siswa kelas x semester genap smk negeri 1 metro tp 2015-2016. Jurnal pendidikan ekonomi um metro, e-issn : 2442-4994 vol.4. no.2 (2016) 61-68.

Kemenkes RI. (2020). Peraturan Menteri Kesehatan Republik Indonesia Nomor 9 Tahun 2020 Tentang Pedoman Pembatasan Sosial Berskala Besar Dalam Rangka Percepatan Penanganan Corona Virus Disease 2019 (Covid- 19). Kementerian Kesehatan RI, 28. http://hukor.kemkes.go.id/uploads/pro uk_hukum/PMK_No_9_Th_2020_tt JURNAL KOLABORASI RESOLUSI KONFLIK VOLUME 2 NOMOR 2 HALAMAN 157-163 ISSN 2655 ISSN 2656- -8823 (1786 $(p e)$ ) 163 gPedoman_Pembatasan_Sosial_Bersk ala_Besar_Dalam_Penanganan_COVI D-19.pdf

Lin, S. H., \& Huang, Y. C. (2014). Life stress and academic burnout. Active Learning in Higher Education, 15(1), 77-90. doi:10.1177/1469787413514651

Lumban Gaol, N. T. (2016). Teori Stres: Stimulus, Respons, dan Transaksional. Buletin Psikologi, 24(1), 1. https://doi.org/10.22146/bpsi.11224

Lyon, B. L. (2012). Handbook of stress,coping and health: Implications for nursing research, theory, and practice. US: Sage Publication, Inc.

Mendikbud RI. (2020). Surat Edaran Nomor 4 Tahun 2020 Tentang Pelaksanaan Kebijakan 
Pendidikan Dalam Masa Darurat Penyebaran Coronavirus Disease (COVID-19). 1- 3. https://www.kemdikbud.go.id/

Poluan, C., \& Pangemanan, S. S. (2015). Analisis penerapan metode direct costing terhadap penentuan harga pokok produksi pada pt. Bangun wenang beverage company, Jurnal EMBA, 3(2), 24-42. Diambil dari https://ejournal.unsrat.ac.id/index.php/emba/article/view/6564.

Renaldi. (2014). Studi minat siswa dalam mengikuti senam kesegaran jasmani di sdn sunju kecamatan marawola kabupaten sigi. E-journal tadulako physical education, health and recreation, 2(6), 1-14. Dari jurnal.untad.ac.id/jurnal/index.php/PJKR/article/view/3488.

Stahl, B., \& Goldstein, E. (2010). A mindfulness-based stress reduction workbook. Oakland: New Harbinger Publication.

Susanna. (2017). Penerapan TGT melalui media kartu domino pada materi minyak bumi. Lantanida Journal, 5 (12). 93-196.

World Health Organization (WHO). Mental disorders fact sheets (Internet). World Health Organization. 2017 (Diakses April 2018). Tersedia dari: http://www.who.int/mediacentre/factsheets/fs396/en/ 